\title{
How to publish in ACRL: Non-serial publications
}

Are you working on a survey, directory, pamphlet, bibliography, or any other project with publication potential? Then you need to be aware of the publication procedures for non-serial publications developed by the ACRL Publications Committee.

If your idea is appropriate for the Publications in Librarianship series, contact the editor, Jonathan A. Lindsey, Coordinator of Library Affairs, Baylor University, Waco, TX 76798. If your idea is appropriate for a CLIP Note, contact the chair of the CLS Clip Note Committee, Pamela Snelson, Coordinator of Access Services, Drew University Library, Madison, NJ 07940.

If your idea is more appropriate as an ACRL non-serial publication, your proposal will go through the following steps on the way.

Step One. Fill out a "Preliminary Publication Information Form," available from ACRL Headquarters, early in the planning stages of your project. This form asks for basic information about the scope and content of the proposed publication and the individual(s) responsible for developing it. Send the completed form to Mary Ellen Davis, ACRL's publications officer, at ACRL Headquarters.

Step Two. The ACRL publications officer reviews the proposal and offers ALA Publishing Services the first chance of accepting the project as an
ALA publication. This "right of first refusal" is specified in the operating agreement between ALA and its divisions.

Step Three. ACRL's Publications Subcommittee on Non-Serial Proposals and the ACRL publications officer review the content and viability of the proposal and make a recommendation as to its feasibility. (In some cases, an outside reader with expertise in the subject area will be asked to review the publication for editorial content. This review will next be considered by the Subcommittee and the publications officer.) The Subcommittee will review and act upon publication proposals throughout the year, as well as at ALA annual conferences and midwinter meetings.

Step Four. After reviewing the recommendations of the Subcommittee (and any outside reviewers) the ACRL publications officer then accepts, rejects, refers back to ALA Publishing Services, or asks for further development of each proposal from the author or sponsoring body.

Step Five. If your proposal is accepted, submit your completed manuscript to ACRL Headquarters for further review by the Subcommittee and the ACRL publications officer.

For further information, contact Mary Ellen Davis, ACRL Publications Officer, ACRL/ALA, 50 E. Huron St., Chicago, IL 60611-2795; (312) 944-6780, x287.

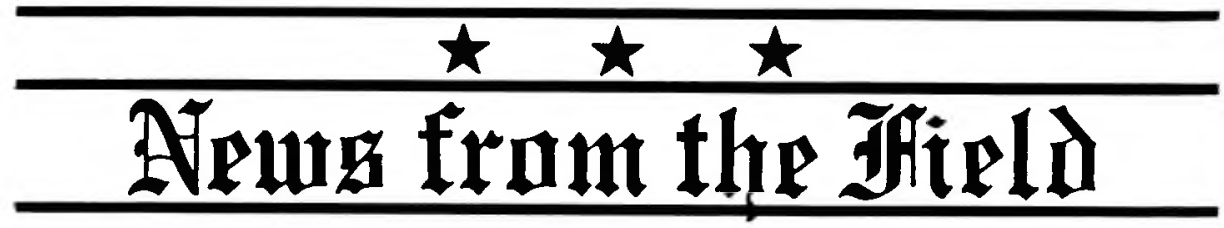

\section{Acquisitions}

- Southeast Missouri State University, Cape Girardeau, has acquired the largest private collection in the world of books and manuscripts by author William Faulkner, valued at $\$ 3.5$ million. The collection was donated by Louis Daniel " $L$. D." Brodsky, a St. Louis poet who collected the material and who will serve as curator, and his father, Saul L. Brodsky, a St. Louis businessman. Most notable among the 10,000 items in the collection are Warner Bros. files and screenplays from Faulkner's stints as a Hollywood screenwriter in the 1940s, more than 120 books inscribed by Faulkner, three one-of-a-kind "books" typed and bound by Faulkner, and the 606-page carbon typescript of "The Hamlet," the only Faulkner novel manuscript not held by an institution. The collection also includes an assortment of personal letters to, from, and about Faulkner, including previously unpublished letters by his wife Estelle, his early mentor Phil Stone, and his Random House editor and confidante Saxe Commins.

-The University of Michigan, Ann Arbor, has acquired the "Lon G. Nungesser Papers: Hope for Humanity" for its Joseph A. Labadie Collection, part of the University's Department of Rare Books and Special Collections. Nungesser, a social psychologist, author, and AIDS victim, donated his papers to the Labadie Collection, one of the largest 
collections of radical activist material in the country, so that his work will be preserved as a foundation, and a departure point, from which to build medical and social systems that promote a healthier personal psychology. Diagnosed with AIDS in 1983 and given a prognosis of death within six months, Nungesser rejected medical advice and developed his own treatment, concentrating on aerobics, vitamins, meditation, and the creation of a positive living environment. His papers include correspondence, drafts of unpublished writings, articles, videotapes and cassettes of interviews, and copies of his three books, Homosexual Acts, Actors and Identities, Epidemic of Courage: Facing AIDS in America, and Notes on Living Until We Say Goodbye: A Personal Guide.

The University has also acquired a limited edition portfolio called "More Printing for Theater: A Portfolio of Ephemera" as a first gift from the Friends of the University of Michigan Library. The portfolio is a collection of memoirs and original creations by the late printer and book designer Adrian Wilson (1923-1988) who was born in Ann Arbor. One of the founders in 1947 of the Interplayers Theater Company in San Francisco, Wilson created announcements, posters, programs, and other printed items for the theater. The portfolio includes original creations for the Interplayers, including rare woodblock and linoleum-cut prints.

-The Wheelock College Library, Boston, has acquired a collection of historical children's books from alumna Martha Wheatley Ingraham. The more than 500 British and American volumes date primarily from the 19 th century but span the mid18 th through 20 th centuries. Included are a battledor, chapbooks, miniatures, primers, and other early textbooks, as well as works by such wellknown authors and illustrators as Caldecott, Cruikshank, Crane, Carroll, Potter, Rackham, Greenaway, Parrish, Milne, and Shepard.

\section{Grants}

- Auburn University, Alabama, has received a $\$ 246,514 \mathrm{NEH}$ grant to support 640 reading and discussion sessions in Alabama libraries focusing on southern literature.

- The Brown University Library, Providence, Rhode Island, has received a $\$ 197,653$ HEA Title II-C grant to convert to machine-readable form the bibliographic records for the monographs in the John Hay Library. The grant will fund the second year of this three-year project. During the first year 70,000 bibliographic records were converted; during the second year another 52,000 records, focusing on the records from the Harris Collection of American Poetry and Plays and other special collections, will be converted. The records produced through the conversion project will be loaded into the RLIN and OCLC online databases, making them available to scholars around the country as well as at Brown.

In addition, the University's John Carter Brown Library has received a $\$ 10,500 \mathrm{NEH}$ grant for the planning of an international conference, an exhibition with interpretive catalog, and public lectures on how New World discoveries influenced European ideas about civilization.

-The California School of Professional Psychology has received a $\$ 75,000$ grant from the Fletcher Jones Foundation to begin automating the libraries across the four-campus CSPP system. The libraries will use the microcomputer-based Sydney data system.

- The Center for Research Libraries, Chicago, Illinois, has been awarded a $\$ 90,642 \mathrm{NEH}$ grant for preservation of newspapers produced by the men in the Civilian Conservation Corps camps from about 1934 to 1938 . The grant will enable the Center to film the papers, produce service copies in microfiche, and produce a printed bibliographic guide that indexes the titles, companies, and geographic locations of the camps. It is estimated that there are over 3,000 titles in the collection.

-Doane College, Crete, Nebraska, has received a $\$ 47,887$ grant from the Department of Education for a cooperative journals sharing project among members of PICKLE, a consortium of nine independent college libraries in Nebraska that also includes the College of St. Mary, Concordia Teachers College, Creighton University, Dana College, Hastings College, Midland Lutheran College, Nebraska Wesleyan University, and Union College. The grant will cover the costs of a comprehensive serials study and the purchase of telefacsimile machines for each library.

- The Fenway Library Consortium, Boston, received a $\$ 35,000$ LSCA Title III Special Project grant to add member library holdings to OCLC's union list of serials. The project resulted in bibliographic access to over 7,000 titles both online and through a printed list.

-The Indiana University Libraries and nine sister institutions have been awarded two grants for a coordinated preservation microfilming project. The outright and matching funds total $\$ 909,781$ from NEH and $\$ 370,000$ from the Mellon Foundation for a three-year grant period that began in October 1988. The project, shared by the universities of Chicago, Illinois, Indiana, Iowa, Michigan, Michigan State, Minnesota, Northwestern, Ohio State, and Wisconsin, will result in the preservation of more than 22,000 volumes from collections important for research in Western European literature and history, African studies, Slavic and Eastern European studies, and the history of science and technology. The IU libraries will use its share of the grant to microfilm and catalog 1,500 volumes of rare Slavic periodicals. 
-The North Carolina State University, Raleigh, library system has received a $\$ 36,357$ HEA Title IID grant to expand its services throughout the state via electronic networks. NCSU holdings are listed in its online catalog, the Bibliographic Information System, developed by the Triangle Research Libraries Network comprised of NCSU, the University of North Carolina at Chapel Hill, and Duke University. By 1989 an automated circulation component will give users across the state expanded access to BIS and the TRLN libraries' collections.

- The Ohio State University Libraries, Columbus, has received a two-year $\$ 115,000 \mathrm{NEH}$ grant to assist in the completion of a comprehensive computerized database of approximately 14,000 titles of American fiction published from 1901 through 1925. The project's goal is to make available a comprehensive bibliographic resource that is not only accurate in content and structure, but adaptable for future additions and modifications, and can be made inexpensively available online, in microform, or on magnetic tape to the scholar-user. Al records will appear in the Online Union Catalog maintained by OCLC and will be made available to RLIN.

-Southern Methodist University, Dallas, Texas, has received a $\$ 220,073$ grant from the U.S. Department of Education to complete the intracampus telecommunications network for the Library Automation Program. The two-year project funds the internal wiring of the libraries to support 200 terminals and printers in the multiple library and media facilities on campus. The grant also supports connecting hardware within the libraries to the SMU ISN network cable and in Bradfield Computer Center. This will place the Central University Libraries into regional, state, and national communication systems supported by Bradfield Computer Center for sharing information on library resources.

-The University of British Columbia, Vancouver, has been awarded a $\$ 37,000$ Social Sciences and Humanities Research Council grant to its Special Collections. The grant, under the Canadian Research Tools Programme, will make possible a computerized catalog of the library's unique Canadian pamphlet collection of more than 20,000 pamphlets on subjects like Canadian history, politics, and literature, with emphasis on British Columbia, voyages of exploration to the west coast of North America and the Arctic, the fur trade, the War of 1812, Canadian railway history, the Riel Rebellion, and the 1837 Rebellion. The computerized catalog will make the collection accessible to all library users, and 200 UBC Library-produced microfiche sets of the catalog will be distributed to university, college, and public libraries throughout Canada.

-The University of California, Berkeley, has received a $\$ 192,000$ grant from the Department of
Education for the second year of its East Asiatic Library's project to catalog and carry out conservation work on special collections of Japanese materials. The grant will enable the University to complete the cataloging of the 5,645 volumes published between 1868 and 1945 acquired from the Mitsui Library in Japan. The four professional Japanese librarians working on the project will also process 2,500 works of contemporary literature and criticism selected from the personal library of the distinguished author Endo Shusaka. In addition, the grant will provide funds for preservation care for the two collections to repair bindings and place volumes with soft covers in protective portfolios. Conservation care will also be given to the collection of 2,877 titles of Japanese manuscripts from the Mitsui Library, dating from the 14th to the early 20 th centuries, which were cataloged in 1983.

- The University of Michigan, Ann Arbor, has received an $\$ 18,539 \mathrm{NEH}$ grant to support the planning of a series of public programs that explore the Jewish role in the discovery, conquest, and settlement of the New World.

- Wake Forest University, Winston-Salem, North Carolina, has received a $\$ 105,990 \mathrm{NEH}$ grant to support a series of lectures, a continuing education course, and other presentations examining the thought of the Constitution's framers in light of competing ideas about man, nature, and politics that have emerged since 1789 .

\section{News notes}

- North Carolina State University, Raleigh, recently created its Friends of the Library Author of the Year Program and awarded young, awardwinning writer Kaye B. Gibbons of Raleigh as its first resident author. The program, thought to be unique among academic libraries, was announced by NCSU director of libraries Susan K. Nutter as part of the Libraries' celebration of their centennial year in 1989. It is intended to assist a series of promising new authors, especially those associated with NCSU, in their literary careers. Gibbons, 27, a native of Nash County, North Carolina, received international acclaim with her first novel Ellen Foster, published in 1987 by Algonquin Books. In May 1988 the novel was awarded both the Sue Kaufman Prize for First Fiction by The American Academy and Institute of Arts and Letters, and a PEN/Hemingway First Novel Citation. During their tenure as authors of the year, Gibbons and her successors will be able to use the Friends of the Library study carrel at D. H. Hill Library as well as other library resources, and will be included in the libraries' social functions.

- The University of Michigan Library, Ann Arbor, has hired two information specialists to coordinate the new M-Link project-a five-year pro- 
gram that will, in time, bring the resources of the University Library closer to the citizens of Michigan through their local public libraries. Wendy $P$. Lougee, head of Harlan Hatcher Graduate Library, has been named M-Link project director and will be responsible for long-range planning and policy decisions. Kathleen M. Bergen, former head of the UM Map Library, will serve as M-Link librarian and will be the primary liaison with $\mathbf{M}$ Link sites. With the M-Link project, Michigan communities will have, for the first time, direct access to the UM Library, the sixth largest academic library system in the country.

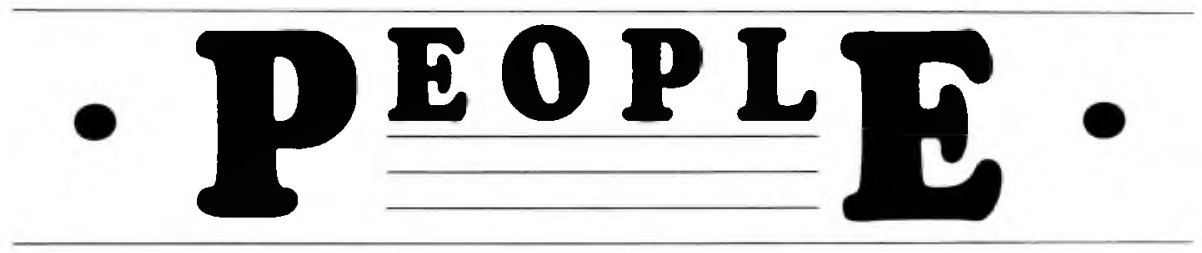

\section{Profiles}

MEREDITH A. BUTLER, assistant vice president for academic planning and development at the State University of New York at Albany, has been appointed director of university libraries and dean of the library faculty at the same institu. tion, effective February 1. Butler has also served as associate for academic development and assistant director for planning and resources development in the SUNY at Albany libraries; head of public services at SUNY at Brockport; and bibliog-

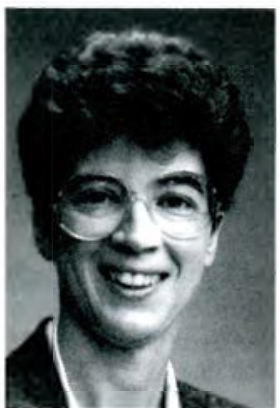

Meredith A. Butler rapher and head of the

Humanities Department at Syracuse University. She earned her BA and MA degrees at Ohio State University, and her MLS from Syracuse University. Awarded the State University of New York Chancellor's Award for Excellence in Librarianship in 1980, Butler is also active in ACRL, the Library Administration and Management Association, the National Women's Studies Association, and the National Association of Women Deans, Administrators and Counselors. She has published on a variety of subjects including copyright, the impact of technology on libraries, and electronic publishing, and has been a frequent speaker at state and national meetings on such topics as women and leadership development, fundraising, planning, and the future of libraries.

RUth Moore Jackson, assistant director of libraries and chief administrator of public services at the University of North Florida, Jacksonville, for the past four years, has been named dean of libraries at West Virginia University, Morgantown. In her new role, Jackson will be responsible for development and management of the $\mathbf{2 . 5}$ million volumes and microforms contained in the Charles C. Wise, Jr. Library and its nine branches on three campuses. She will also oversee the West Virginia and Regional History

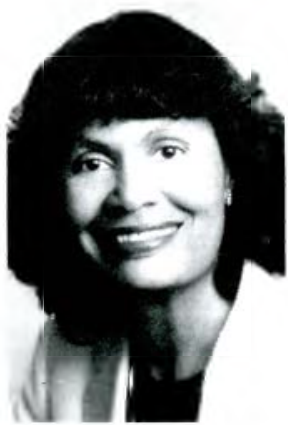

Ruth Moore Jackson Collection which contains over 4.5 million manuscript items.

Jackson received her bachelor's degree from Hampton Institute, her MLS from Atlanta University, and her Ph.D. from Indiana University. Before joining the staff at UNF she held the positions of assistant education librarian, head reference librarian, and associate professor and coordinator of the library science program at Virginia State University. She has served as visiting lecturer and teaching fellow at Indiana University and as visiting cataloger at Monroe County Public Library in Bloomington, Indiana. She is a member of ALA, ACRL, the Florida Library Association, and the Southeastern Library Association, and has served on a variety of academic committees and university service organizations. An active participator in numerous professional conferences and seminars, Jackson has contributed to two textbooks and is currently researching a third dealing with personnel management for libraries. 